\title{
Futebol e ditadura militar no Brasil: o episódio brasileiro da série Memórias do Chumbo: o futebol nos tempos do Condor
}

\author{
Football and Military Dictatorship in Brazil: the Brazilian episode of \\ Memórias do Chumbo: o futebol nos tempos do Condor
}

Lucas Toledo Gonçalves

Universidade Federal de São João del-Rei (UFSJ), São João del-Rei/Brasil

Mestre em História, UFSJ

lucas_toledo08@hotmail.com

Pensar a relação entre futebol e ditadura militar na América do Sul é compreender que o esporte é, em primeiro lugar, um importante fator de mobilização social e elemento imprescindível na cultura coletiva da região. A relação do povo sulamericano com o futebol apresenta-se como íntima e passional. Desde que desembarcou das terras europeias, nas últimas décadas do século XIX, o esporte se constituiu como um dos fenômenos sociais mais abrangentes do continente, quiçá o maior. ${ }^{1}$ Ao ser incorporado no imaginário coletivo, ele tornou-se capaz de atribuir fundamento e significado aos desejos e anseios da grande maioria da população de países como Argentina, Brasil, Chile e Uruguai. Nesses países, embora o futebol tenha sido disseminado entre os grupos mais elitizados da população nos primórdios do século XX, rapidamente chegou às camadas populares, se tornando um fenômeno de massa, um espetáculo capaz de promover grandes vínculos de solidariedade e de canalizar fluxo de emoção coletiva.

No Brasil, desde a década de 1930, o futebol é considerado um dos pilares dos discursos da identidade nacional. A comoção dos brasileiros para com o esporte fez com que este se tornasse um dos maiores elementos simbólicos do país; o qual, através das conquistas no campo futebolístico, se afirmou, evidentemente, como um bem nacional e cultural, capaz de sustentar discursos e oferecer possibilidades de capitalização. Neste sentido, o campo futebolístico passou a encampar as disputas ideológicas entre diversos agentes sociais, servindo

${ }^{1}$ ALABARCES. Fútbol y pátria. 
também como disseminador das políticas estatais, consolidando uma relação estabelecida pelo "uso político do esporte e o uso da política pelo esporte", 2 onde as esferas do poder, da política e das ideologias também se reproduziam dentro das quatro linhas e nas arquibancadas. 0 período marcado pelos regimes ditatoriais nos países supracitados foi, sem dúvida alguma, um dos momentos em que todas essas questões, ou boa parte delas, estiveram mais próximas e interligadas. ${ }^{3}$

Com o objetivo de demonstrar a relação entre os regimes ditatoriais do Cone Sul e a apropriação política do futebol, o jornalista e também historiador Lúcio de Castro, no exercício de sua atividade como profissional do canal esportivo ESPN BRASIL, percorreu o continente sul-americano em busca de histórias e memórias, que fossem esclarecedoras e pioneiras sobre a relação entre as ditaduras militares e o futebol na Argentina, Brasil, Chile e Uruguai. Com efeito, no intuito de contribuir com o resgate e a preservação da memória referente ao período, o jornalista reuniu relatos importantes de atores que vivenciaram in locu alguns acontecimentos, que ratificam a apropriação política e a militarização do campo futebolístico nestes países. A reunião do conteúdo material, oral, e acima de tudo histórico, resultou na produção da série de documentários Memórias do Chumbo: o futebol nos tempos do Condor, produzida e lançada no ano de 2012 e composta por um total de quatro filmes - ou episódios -, cada qual responsável por contar as histórias e resgatar os fragmentos das memórias de argentinos, brasileiros, chilenos e uruguaios que permaneceram ocultas durante muito tempo.

Os trabalhos de reportagem, roteiro e produção em Memórias do Chumbo renderam a Lúcio de Castro reconhecimento nacional e internacional. A série recebeu, em 2013, o Prêmio Gabriel García Márquez na categoria Cobertura de Notícias. 0 evento é inspirado no próprio Gabriel García Márquez, considerado um dos grandes autores e jornalistas do século XX. O prêmio é organizado pela Fundación Nuevo Periodismo Iberoamericano (FNPI) e contou com a participação de 1.379 trabalhos de 30 países, sendo 174 do Brasil. A série foi também finalista do Prêmio Esso de Jornalismo de 2013, além de ter sido selecionada para o Festival

\footnotetext{
${ }^{2}$ GUTERMAN. O futebol explica o Brasil.

${ }^{3}$ Cf. FRANCO JúNIOR. A dança dos deuses.
} 
de Filmes Esportivos de Milão, na Itália, para o Festival de Cinema de Havana, em Cuba, e para o Festival de Cinema de Futebol de 2013 (CINEfoot).

Aqui, nos deteremos exclusivamente no episódio brasileiro da série. Para que o leitor tenha maior dimensão acerca desse filme documentário específico, é necessário destacarmos que o mesmo é composto por um conjunto de blocos narrativos arquitetados com o objetivo de construir uma organicidade, estrutura e cronologia à narrativa. Estes blocos correspondem a diferentes perspectivas e abordagens: 1) abertura e contextualização histórica brasileira e sul-americana que antecederam 1964, e conjunturas políticas internas e externas que levaram ao golpe; 2) os primeiros anos do regime militar e o despertar dos militares para as potencialidades de apropriação do futebol; 3) relação futebol e ditadura militar Copa do Mundo de 1966; 4) anos de chumbo do regime - recrudescimento do autoritarismo e mecanismos de controle social; 5) vigilância sobre personagens ligados ao futebol: caso João Saldanha; 6) militarização da seleção brasileira de futebol; 7) relação futebol e ditadura militar - Copa do Mundo de 1970; 8) aumento da vigilância sobre personagens ligados ao futebol - casos Afonsinho, João Havelange e Pelé; 9) a Operação Condor e sua ligação com o futebol; 10) considerações finais.

Peças fundamentais na composição do documentário são os historiadores Carlos Eduardo Sarmento e Carlos Fico, especialistas no tema e cujas falas reforçam a interpretação dos fatos abordados, fornecendo uma aura de cientificidade à narrativa do documentário. A composição dos contextos históricos também é realizada pela trilha sonora do filme, composta por cinco canções principais: "Chega de saudade", de Tom Jobim, símbolo da Bossa Nova, da influência da cultura norte-americana no cotidiano brasileiro, em referência à década de 1950 e ao boom de desenvolvimento da indústria nacional;; "Sou tricampeão", da banda Golden Boys, como exemplo da instrumentalização política da cultura popular empreendida pela ditadura; "Pra não dizer que não falei das flores”, de Geraldo Vandré, "Paiol de pólvora”, de Vinícius de Moraes, e "Apesar de você", de Chico Buarque, representando o recrudescimento do regime no final dos

\footnotetext{
${ }^{4}$ TINHORÃO. Música popular.
} 
anos 1960 e a resistência político-cultural. Esta última tocada na sequência final do filme, em uma clara menção à busca pelo resgate das memórias perdidas durante a ditadura militar, desejo manifestado durante todo o documentário de formas variadas.

É nessa perspectiva, portanto, que podemos dizer que o que torna a produção fílmica única em seu segmento são os depoimentos, por vezes inéditos, prestados por indivíduos que estiveram diretamente inseridos no mundo histórico tratado pelo filme. Destaque nesse sentido para a fala de Eduardo Guaranys, sobrinho do major Roberto Câmara Ipiranga dos Guaranys, homem de confiança do regime militar que se tornou um dos responsáveis pela proteção interna da seleção brasileira de futebol que disputou a Copa do Mundo de 1970 no México e pela comunicação entre ela e a ditadura.

Através desses depoimentos, o documentário expressa também um discurso subjetivo, no qual os convidados são dotados de uma profundidade psicológica que passa a ser um objetivo para quem os convidou, fazendo com que as questões maiores que permeiam toda a trama apareçam de forma implícita. Os indivíduos são então representados como únicos, e o caráter privativo de suas falas ganha destaque. Exemplo disso se dá com a participação do jornalista Luis Cláudio Cunha, que relata o envolvimento de pessoas ligadas ao futebol na Operação Condor, uma espécie de aliança militar e política entre os regimes militares da América do Sul, que tinha como objetivo central a destruição permanente de toda e qualquer resistência às ditaduras.

Vale ainda mencionar que a obra foi produzida em um momento importante do contexto social brasileiro, sobretudo no campo dos esportes. 0 ano de lançamento do documentário (2012) antecede a realização de três megaeventos esportivos que tiveram o Brasil como país sede: a Copa das Confederações, em 2013, a Copa do Mundo em 2014 - ambas organizadas pela FIFA (Fédération Internationale de Football Association) - e os Jogos Olímpicos, em 2016, organizados pelo COI (Comitê Olímpico Internacional). Desde 2010, supostos casos de corrupção nas entidades que controlam o futebol e os esportes olímpicos mundiais e brasileiros passaram a ocupar um espaço cada vez maior no noticiário nacional, como as acusações que apontaram irregularidades nos contratos da Copa 
do Mundo de 2014 e que motivaram a renúncia do então presidente da CBF (Confederação Brasileira de Futebol), Ricardo Teixeira, que esteve à frente do cargo por vinte e três anos.

\section{REFERÊNCIAS}

ALABARCES, Pablo. Fútbol y pátria: el fútbol y las narrativas de la nación en la Argentina. Buenos Aires: Prometeu Libros, 2008.

FRANCO JÚNIOR, Hilário. A dança dos deuses: futebol, cultura, sociedade. São Paulo: Companhia das Letras, 2003.

GUTERMAN, Marcos. O futebol explica o Brasil: uma história da maior expressão popular do país. São Paulo, Contexto, 2009.

MEMÓRIAS do Chumbo: o futebol nos tempos do Condor. Brasil. Direção: Lúcio de Castro. Brasil, 2012 (52 min.), son., color.

TINHORÃO, José Ramos. Música popular: um tema em debate. $3^{\mathfrak{a}}$ ed. São Paulo: Ed. 34, 1997. 